\title{
Barbiturate blood levels found at necropsy in proven cases of acute barbiturate poisoning
}

\author{
ROGER GILLETT AND FRANK G. WARBURTON \\ From the Department of Pathology, Hope Hospital, Salford, Lancs
}

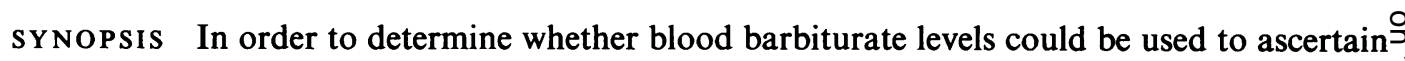
that death had been caused by barbiturate overdose, samples of blood from 128 subjects of coroners' necropsies were examined for barbiturate content. Sixty of these were well authenti $\stackrel{\ulcorner}{<}$ cated cases of barbiturate overdosage, and barbiturates were implicated, together with other $\vec{\theta}$ factors such as alcohol and carbon monoxide, in a further 16 cases. The remaining 52 cases. ${ }^{\circ}$ were of an eliminatory nature, 10 of which had low barbiturate blood levels considered to be within the therapeutic range.

The results indicate that when the accepted levels producing loss of consciousness are exceeded, and maintained, death will ensue if treatment is not given. These results may be of value in assessing findings in necropsies requested by the coroner, and are in no way applicable $\Rightarrow$ to the living patient in whom it is well established that recovery from higher blood levels $\cong$ may take place if adequate treatment is available.

Anatomical evidence of barbiturate poisoning at necropsy is not specific, often amounting only to signs of asphyxia. The presence of powder or remnants of capsules in the oesophagus or stomach and the inflammatory reaction of the gastric mucosa are useful indications, but not always present, so that the diagnosis may depend on the absence of other causes of death and suspicions raised by information about missing tablets, leading to the search for barbiturate in the blood or other organs.

Although rapid and accurate methods are available for the detection and estimation of barbiturates in biological material (Broughton, 1956), there is still uncertainty as to what blood levels are enough to cause death, since there is considerable overlap between the fatal and non-fatal levels demonstrated after overdosage.

The lowest blood barbiturate levels quoted by Fisher (1949) in fatal cases were $2.0 \mathrm{mg} / 100 \mathrm{ml}$ for short and intermediate-acting barbiturates and $9.8 \mathrm{mg} / 100 \mathrm{ml}$ for long-acting barbiturates, Received for publication 11 September 1969. but he notes that it must not be inferred that finding these levels constitutes prima facie evidence of death from barbiturate poisoning.은 At least three studies (Fisher, 1949; Broughton, $>$ Higgins, and O'Brien, 1956; Curry, 1963)을 have given blood levels at which unconsciousness occurs (Table I), and Broughton et al (1956) ${ }^{\circ}$ have suggested that death is likely to supervene $\sim$ when the blood level exceeds $3 \mathrm{mg} / 100 \mathrm{ml}$ of $\mathrm{w}_{\mathrm{w}}$ short-acting, $7 \mathrm{mg} / 100 \mathrm{ml}$ of intermediate- 0 acting, and $10 \mathrm{mg} / 100 \mathrm{ml}$ of long-acting bareo biturates.

For some years it has been our practice to $\stackrel{?}{?}$ estimate the blood barbiturate levels in deaths when poisoning was suspected. At first results were assessed by reference to the levels suggested by Broughton et al (1956) as sufficient to cause death. It soon became clear, however, thato these levels were too high, since there were many cases of undoubted barbiturate poisoning, with no other contributory cause, dying with considerably lower blood barbiturate levels.

It was then realized that those in coma were 


\begin{tabular}{|c|c|c|c|c|c|c|}
\hline \multirow[t]{3}{*}{ Barbiturate } & \multicolumn{6}{|c|}{ Barbiturate Levels $(\mathrm{mg} / 100 \mathrm{ml})$} \\
\hline & \multirow{2}{*}{$\begin{array}{l}\begin{array}{l}\text { Gillett \& } \\
\text { Warburton }\end{array} \\
\text { Necropsy }\end{array}$} & \multirow{2}{*}{$\begin{array}{l}\text { Curry (1963) } \\
\text { Return of } \\
\text { Consciousness }\end{array}$} & \multicolumn{2}{|c|}{ Broughton et al (1956) } & \multicolumn{2}{|l|}{ Fisher (1949) } \\
\hline & & & $\begin{array}{l}\text { Return of } \\
\text { Consciousness }\end{array}$ & Death & $\begin{array}{l}\text { Loss of } \\
\text { Consciousness }\end{array}$ & Necropsy \\
\hline \multirow[t]{2}{*}{ Short acting } & $\begin{array}{l}0 \cdot 96-5 \cdot 2^{1} \\
(36 \text { cases) }\end{array}$ & $0 \cdot 8$ & $\begin{array}{l}1 \cdot 3-1 \cdot 7 \\
(4 \text { cases })\end{array}$ & $3 \cdot 0^{2}$ & & \\
\hline & & & & & $1 \cdot 0-3 \cdot 2$ & $\begin{array}{l}2 \cdot 0-7 \cdot 5 \\
(7 \text { cases) }\end{array}$ \\
\hline Intermediate & $\begin{array}{l}2 \cdot 2-5 \cdot 9^{1} \\
(22 \text { cases) }\end{array}$ & $2 \cdot 0-3 \cdot 0$ & $\begin{array}{l}1 \cdot 7-4 \cdot 2 \\
(10 \text { cases) }\end{array}$ & $7 \cdot 0^{2}$ & & \\
\hline \multirow[t]{2}{*}{$\begin{array}{l}\text { Long acting } \\
\text { Phenobarbitone }\end{array}$} & $\begin{array}{l}12 \cdot 1^{1} \\
(1 \text { case })\end{array}$ & $5 \cdot 0$ & $\begin{array}{l}5 \cdot 0-8 \cdot 9 \\
(6 \text { cases })\end{array}$ & & & \\
\hline & & & & $10 \cdot 0^{2}$ & $\begin{array}{l}7 \cdot 0-12 \cdot 0 \\
(7 \text { cases })\end{array}$ & $\begin{array}{l}9 \cdot 8-34 \cdot 0 \\
(3 \text { cases })\end{array}$ \\
\hline Barbitone & $\begin{array}{l}5 \cdot 1^{1} \\
(1 \text { case })\end{array}$ & $8 \cdot 0$ & $\begin{array}{l}6 \cdot 9-7 \cdot 8 \\
(3 \text { cases) }\end{array}$ & & & \\
\hline
\end{tabular}

Table I Blood barbiturate levels found at necropsy compared with levels at loss or return of consciousness 'Figures adjusted to a supposed $100 \%$ extraction (see text) for comparison with those of other authors.

'Levels suggested by Broughton $e t$ al as being 'compatible with death from barbiturate poisoning'.

likely to die if they received no treatment, so that the coroner's question, 'Was death due to barbiturate poisoning?' must be answered by reference to the blood levels known to cause unconsciousness.

\section{Materials and Methods}

During the past six years, blood and stomach contents from 128 cases of suspected barbiturate poisoning, on which necropsies had been requested by the coroner, have been examined. Most of them were found dead and the remainder died before any resuscitative measures could be applied. In 60 of these cases there was clear evidence in the form of suicide notes, missing tablets, and absence of other causes of death, which led to suspicion of barbiturate poisoning. Police evidence indicated that no other complicating factors were involved and barbiturates only were implicated in the death. In another 16 cases, however, other factors were involved together with barbiturates. In a few of these cases there was a possibility that death had been brought about accidentally, but most of them were undoubtedly suicidal. By contrast, there was no evidence of suicidal attempt in the remaining 52 cases, where the chemical investigations were of a purely eliminatory nature and undertaken simply because barbiturate was known, or thought, to have been prescribed at some previous time. In 10 of these 52 cases, barbiturate was found in the blood. A cause of death, other than barbiturate poisoning, was found at necropsy in all 52 cases.

The blood barbiturate levels were determined by ultraviolet spectrophotometry (Unicam, 1960; Broughton, 1956) after straightforward chloroform extraction of the blood. Full absorption spectra were always obtained and checked for correctness of points of identification.
Previously when this method had been usect to determine blood barbiturate levels in prepared specimens where barbiturate had been added to the blood, a recovery rate of 85 to $95 \%$ hade been obtained. There is some evidence that the recovery rate is dependent on the type of barbit $\vec{\imath}$ urate present, so that ideally a separate specifict extraction factor should be applied for each type of barbiturate. This caused some concerne at the time of the earlier investigations as pure samples of the various barbiturates were not then readily available for determination of these factors. Moreover, recovery of barbiturate added to blood is not necessarily comparables with the recovery of barbiturate assimilated into the blood stream. In order to take accoun of this and our failure to obtain $100 \%$ recovery. rates in experiments with added barbiturate, wo applied a recovery rate of $80 \%$ to all our estimations.

Since it is not the usual practice to use की correction factor for recovery, the figures representing a $100 \%$ extraction rate have beeno listed in Table I for comparison with other authors' figures. A further problem caused byㅡ. the lack of suitable barbiturate standards was the necessity to use di-ethyl barbituric acid as $\mathbf{a}^{\mathrm{O}}$ standard. Conversion to the implicated barbit 0 urate was calculated by using the respective molecular weights, although it may be bettero to use absorbance figures and employ the requisite factor (Broughton, 1956).

Because results were required so quicklys by the coroner, very little time was available for complete identification and it was the usuab practice to assign the barbiturate to the class of short-acting, intermediate, or long-acting by a simple alkaline hydrolysis test (Unicam $\bigcirc$ 1960), and sometimes by a simple chromatographic separation (Smith, 1958) to confirmo that the police information regarding the ims plicated barbiturate was correct. These were essentially confirmatory tests, as police informa- 


\begin{tabular}{|c|c|c|c|c|}
\hline \multicolumn{5}{|c|}{ Blood Barbiturate Level $(\mathrm{mg} / 100 \mathrm{ml})$} \\
\hline Short-acting & Short + Intermediate & Short + Carbromal & Intermediate-Acting & Long-acting \\
\hline $\begin{array}{l}\text { Pentobarbitone } \\
\text { (Nembutal) }\end{array}$ & $\begin{array}{l}\text { Quinal + Amylobarbitone } \\
\text { (Tuinal) }\end{array}$ & $\begin{array}{l}\text { Pentobarbitone } \\
\text { (Carbrital) }\end{array}$ & $\begin{array}{l}\text { Amylobarbitone } \\
\text { (Amytal) }\end{array}$ & $\begin{array}{l}\text { Phenobarbitone } \\
\text { (Phenobarbitone) }\end{array}$ \\
\hline $\begin{array}{l}1 \cdot 2 \\
1 \cdot 3 \\
1 \cdot 4 \\
1 \cdot 5 \\
2 \cdot 0 \\
2 \cdot 3 \\
2 \cdot 4 \\
2 \cdot 5 \\
2 \cdot 7 \\
3 \cdot 0^{1} \\
3 \cdot 4 \\
4 \cdot 1 \\
4 \cdot 4 \\
5 \cdot 0 \\
6 \cdot 5 \\
\\
Q \text { uinalbarbitone } \\
(\text { Seconal) } \\
1 \cdot 7 \\
1 \cdot 7 \\
2 \cdot 9\end{array}$ & $\begin{array}{l}1 \cdot 7 \\
1 \cdot 8 \\
2 \cdot 2 \\
2 \cdot 3 \\
2 \cdot 4 \\
2 \cdot 5 \\
2 \cdot 8 \\
2 \cdot 9 \\
3 \cdot 0 \\
3 \cdot 3 \\
6.4^{1}\end{array}$ & $\begin{array}{l}1.4 \\
1.6 \\
1.6 \\
1.8 \\
1.9 \\
3.6 \\
4.4\end{array}$ & $\begin{array}{l}2 \cdot 9 \\
3 \cdot 0 \\
3 \cdot 0 \\
3 \cdot 1 \\
3 \cdot 4 \\
3 \cdot 4 \\
3 \cdot 5 \\
4 \cdot 1 \\
4 \cdot 7 \\
\text { Sodium amylobarbitone } \\
\text { (Sodium amytal) } \\
2 \cdot 7 \\
2 \cdot 8 \\
2 \cdot 9 \\
3 \cdot 1 \\
3 \cdot 8 \\
4 \cdot 0 \\
4 \cdot 5 \\
4 \cdot 7 \\
\text { Butobarbitone } \\
(\text { Soneryl) } \\
2 \cdot 8 \\
3 \cdot 1 \\
4 \cdot 7 \\
6 \cdot 1 \\
7 \cdot 3 \\
\text { Range. } 2 \cdot 7-7 \cdot 3\end{array}$ & $\begin{array}{l}15 \cdot 1 \\
\text { Sodium barbitone } \\
\text { (Sodium Barbitone) } \\
6.4\end{array}$ \\
\hline Range: $1 \cdot 2-6 \cdot 5$ & Range: $1 \cdot 7-6 \cdot 4$ & Range: $1 \cdot 4-4 \cdot 4$ & Range: $2 \cdot 7-7 \cdot 3$ & Range: $6 \cdot 4-15 \cdot 1$ \\
\hline
\end{tabular}

Table II Blood barbiturate levels found at necropsy in 60 cases of proven barbiturate poisoning

${ }^{1}$ Tungstic acid precipitation

tion was usually complete and reliable. For these reasons no further steps were taken to identify the pairs of drugs present in the cases of Tuinal and Carbrital poisoning. According to the evidence available it was necessary on occasion to test for tranquillizing drugs, etc, when the spot tests listed in the ACP Broadsheet (Curry, 1966) were employed, but this was not instituted as a routine procedure.

When poor or distorted spectra were obtained, larger quantities of blood were extracted. In the case of specimens from subjects long dead, it was sometimes necessary to precipitate the proteins with tungstic acid in order to obtain a satisfactory extract producing an undistorted spectrum (Valov, 1946). It should be pointed out that extraction is then of the order of 50 to $70 \%$ and very low figures should be viewed in this context (Bogan and Smith, 1967).

Stomach contents, when sufficient, were extracted with chloroform, the extract decolorized by boiling with charcoal and then recrystallized from water. This gives a more satisfactory re-crystallization than from acetone, chloroform, or ether, and enables a melting point to be determined fairly rapidly.

\section{Results}

The blood levels for the various types of barbiturate are listed in Tables II-IV. Table II gives the blood barbiturate level for 60 subjects in whom there was strong evidence of overdose $\frac{}{2}$ in the form of missing tablets or capsules, empty containers by the bedside, suicide notes oro confession before the tablets had time to act, and in whom barbiturate overdose was the only cause of death demonstrable at necropsy.

The lowest fatal blood levels were with theo short-acting barbiturates, whether alone or in: combination. The lowest level was $1.2 \mathrm{mg} / 100 \mathrm{ml}$. with pentobarbitone alone. The addition of carbromal to pentobarbitone, as in Carbrital, did not produce lower levels, the lowest in this의 group being $1.4 \mathrm{mg} / 100 \mathrm{ml}$. The lowest fatal $>$ level with Tuinal in which the short-acting quinalbarbitone is combined with intermediate- $N$ acting amylobarbitone was $1.7 \mathrm{mg} / 100 \mathrm{ml}$, which was similar to the lowest level for quinal-o barbitone alone, but higher than the lowest $\omega$ level for pentobarbitone.

The lowest fatal blood level for the interto mediate-acting barbiturates amylobarbitone, so-ळ dium amylobarbitone, and butobarbitone were. $2 \cdot 9,2 \cdot 7$, and $2.8 \mathrm{mg} / 100 \mathrm{ml}$ respectively, significantly higher than the lowest levels of the shortacting barbiturates.

There were only two instances of poisoning $\mathbb{Q}$ with the long-acting barbiturates and no usefulo inference can be drawn as to the lowest level to be found in fatal cases.

In a further 16 cases (Table III), with similar evidence leading to suspicion of barbiturate poisoning, barbiturate was found in the blood 


\begin{tabular}{|c|c|c|c|c|c|c|c|}
\hline \multirow{2}{*}{\multicolumn{2}{|c|}{$\begin{array}{l}\text { Short-acting } \\
\text { Pentobarbitone } \\
\text { (Nembutal) }\end{array}$}} & \multicolumn{2}{|l|}{ Short + Intermediate } & Short + Carbromal & Intermediate-acting & \multicolumn{2}{|l|}{ Long-acting } \\
\hline & & $\begin{array}{l}\text { Quinal }+ \text { Amylobarbitone } \\
\text { (Tuinal) }\end{array}$ & & $\begin{array}{l}\text { Pentobarbitone - } \\
\text { Carbromal } \\
\text { (Carbrital) }\end{array}$ & $\begin{array}{l}\text { Amylobarbitone } \\
\text { (Amytal) }\end{array}$ & Phenobarbitone & \\
\hline $\begin{array}{l}\text { Pentobarbitone } \\
\text { Pulmonary } \\
\text { tuberculosis }\end{array}$ & 0.6 & $\begin{array}{l}\text { Quinal } \div \text { amylobarbitone } \\
\text { Alcohol }\end{array}$ & $\begin{array}{r}0 \cdot 6 \\
200\end{array}$ & $\begin{array}{lr}\text { Pentobarbitone } & 2 \cdot 5 \\
\text { Alcohol } & 218\end{array}$ & $\begin{array}{lr}\text { Amylobarbitone } & 3 \cdot 8 \\
\text { Alcohol } & 225\end{array}$ & $\begin{array}{l}\text { Phenobarbitone } \\
\text { Alcohol }\end{array}$ & $3 \cdot 20$ \\
\hline $\begin{array}{l}\text { Pentobarbitone } \\
\text { Alcohol }\end{array}$ & $\begin{array}{r}2 \cdot 0 \\
22\end{array}$ & $\begin{array}{l}\text { Quinal + amylobarbitone } \\
\text { Alcohol } \\
\text { Traces of Librium }\end{array}$ & $\begin{array}{r}2 \cdot 4 \\
75\end{array}$ & & $\begin{array}{lr}\text { Amylobarbitone } & 4 \cdot 7 \\
\text { Alcohol } & 222\end{array}$ & $\begin{array}{l}\text { Phenobarbitone } \\
\text { Alcohol }\end{array}$ & $50 \frac{\pi}{\frac{\pi}{T}}$ \\
\hline $\begin{array}{l}\text { Quinalbarbitone } \\
\text { (Seconal) }\end{array}$ & & $\begin{array}{l}\text { Quinal + amylobarbitone } \\
\text { Carben monoxide }\end{array}$ & $\begin{array}{l}3 \cdot 3 \\
53 \%\end{array}$ & & $\begin{array}{l}\text { Butobarbitone } \\
\text { (Soneryl) }\end{array}$ & $\begin{array}{l}\text { Phenobarbitone } \\
\text { Alcohol }\end{array}$ & $202 \mathrm{C}$ \\
\hline $\begin{array}{l}\text { Quinalbarbitone } \\
\text { Alcohol } \\
\text { Carbon monoxide }\end{array}$ & $\begin{array}{l}0 \cdot 7 \\
210 \\
2 \cdot 5 \%\end{array}$ & & & & $\begin{array}{l}\text { Butobarbitone } \quad 1 \cdot 6 \\
\text { Asphyxia } \\
\text { (plastic bag) }\end{array}$ & $\begin{array}{l}\text { Phenobarbitone } \\
\text { Also took Welldorm } \\
\text { and had anaemia. }\end{array}$ & \\
\hline $\begin{array}{l}\text { Quinalbarbitone } \\
\text { Carbon monoxide }\end{array}$ & $\begin{array}{l}1 \cdot 3 \\
25 \%\end{array}$ & & & & & & \\
\hline $\begin{array}{l}{ }^{1} \text { Barbiturate } \\
\text { Alcohol }\end{array}$ & $\begin{array}{r}1 \cdot 7 \\
182\end{array}$ & & & & & & \\
\hline \multicolumn{8}{|c|}{ Table III Blood barbiturate levels found in the presence of other compounds and other conditions } \\
\hline \multicolumn{8}{|c|}{ Barbiturate Level $(\mathrm{mg} / 100 \mathrm{ml})$} \\
\hline Short-acting & & Short + Intermediate & & Short + Carbromal & Intermediate-acting & Long-acting & \\
\hline $\begin{array}{l}\text { Pentobarbitone } \\
\text { (Nembutal) }\end{array}$ & & $\begin{array}{l}\text { Quinal }+ \text { Amylobarbitone } \\
\text { (Tuinal) }\end{array}$ & & $\begin{array}{l}\text { Pentobarbitone } \\
\text { (Carbrital) }\end{array}$ & $\begin{array}{l}\text { Amylobarbitone } \\
\text { (Amytal) }\end{array}$ & $\begin{array}{l}\text { Phenobarbitone } \\
\text { (Phenobarbitone) }\end{array}$ & \\
\hline $\begin{array}{l}0 \cdot 6 \\
0 \cdot 6\end{array}$ & & $\begin{array}{l}0.25 \\
0.6 \\
0.6\end{array}$ & & $0 \cdot 5$ & $0 \cdot 75$ & $\begin{array}{l}1 \cdot 2 \\
2 \cdot 6\end{array}$ & \\
\hline $\begin{array}{l}\text { Quinalbarbitone } \\
\text { (Seconal) } \\
0.6\end{array}$ & & & & & & & \\
\hline
\end{tabular}

Table IV Blood barbiturate levels found when death was not primarily due to barbiturate poisoning

and there were other substances such as alcohol, carbon monoxide or other drugs, or other factors such as anaemia, severe tuberculosis, or asphyxia from a plastic bag, which contributed to the cause of death. In eight of these 16 cases the barbiturate level at death was lower than the lowest level when the corresponding barbiturate by itself was involved. Although the plastic bag would have caused death by itself, the alcohol, carbon monoxide, and other factors were not by themselves sufficient to cause death in any of the remaining 15 cases. One of the lowest barbiturate levels in this group was $0.6 \mathrm{mg} / 100 \mathrm{ml}$ pentobarbitone in a subject with severe chronic pulmonary tuberculosis which contributed to cause death at an earlier stage of absorption when there was still $1.2 \mathrm{~g}$ of pentobarbitone recoverable from the stomach. The presence of the equivalent of more than 13 capsules in the stomach confirmed the suspicion of overdose raised by the empty container found by the bedside, a prescription of $30 \times 90 \mathrm{mg}$ capsules of pentobarbitone having been dispensed three days previously.

Most of the cases in Table III were of overdoses of suicidal intent, but in at least two cases death may have been the accidental result of a drinking spree while on heavy therapeutic barbiturate dosage. One of these was a man with blood levels of $0.6 \mathrm{mg} / 100 \mathrm{ml}$ quinal and amylobarbitone and $200 \mathrm{mg} / 100 \mathrm{ml}$ alcohol, and the other a man taking Bellergal (containing bella-o응 donna, ergotamine, and phenobarbitone) for migraine with blood levels of $3.0 \mathrm{mg} / 100 \mathrm{ml}$ phenobarbitone and $202 \mathrm{mg} / 100 \mathrm{ml}$ alcohol. Another man, although taking an overdose of음 barbiturate, may not have intended to commit $>$ suicide. He had been drinking with his wife을 and took a number of amylobarbitone capsules $\mathrm{N}$ with drunken disregard for their additional ${ }^{\circ}$ effect. He died with a blood level of $4.7 \mathrm{mg} / 100 \mathrm{ml}$ N amylobarbitone and $222 \mathrm{mg} / 100 \mathrm{ml}$ alcohol ${ }_{\omega}^{N}$ before his wife could get him to hospital.

By contrast, 10 cases were examined (Table IV) where barbiturate had been prescribed and barbiturate was found in the blood, but there? was no evidence of suicidal intent and no cause 0 of death, other than barbiturate poisoning, had웅 been found. None of the seven using short-acting barbiturates gave blood levels over $0.6 \mathrm{mg} / 100 \mathrm{ml}$. One subject dying in status asthmaticus had ao level of $0.75 \mathrm{mg} / 100 \mathrm{ml}$ of the intermediateacting amylobarbitone. Two subjects dying in status epilepticus had blood phenobarbitone levels of 1.2 and $2.6 \mathrm{mg} / 100 \mathrm{ml}$. No other drugs $\frac{\bar{a}}{2}$ were implicated and these low blood levels were? 
considered to be the result of therapeutic dosage and not contributing to the cause of death.

A further 42 cases of a purely eliminatory nature have been examined, some of them known to have had barbiturate prescribed, but no barbiturate could be found at necropsy.

The amount of barbiturate recovered from the stomach in the cases of barbiturate overdosages was extremely variable. It was worth extracting, if possible, as it could provide evidence of suicidal intent if amounts in excess of the therapeutic dose were recovered. In four of the well authenticated cases of poisoning, however, only small amounts of barbiturate were recovered from the stomach. In these cases the stomach was virtually empty, and it is reasonable to suppose that assimilation had been rapid and complete.

\section{Discussion}

The problem had been to give some guidance to the coroner as to whether death was due to barbiturate poisoning. Previously there has been a tendency to disregard blood barbiturate levels as a parameter mainly because investigations on unconscious patients demonstrated that recovery could often take place with very high levels, whilst such levels had proved fatal in other cases.

From the findings of this investigation it would appear that death from barbiturate poisoning can occur at levels little above the lowest quoted by Fisher (1949), by Curry (1963), and by Broughton et al (1956) as producing unconsciousness. The figures suggested by Broughton et al (1956) as "compatible with death' are clearly too high, since only 10 out of the 60 subjects dying from suicidal overdose of barbitone alone, and none of the 16 subjects dying from barbiturate combined with other factors, had blood levels higher than these. It must be noted that these figures were suggested by Broughton et al (1956) in a paper dealing with blood barbiturate levels in patients being actively treated for acute barbiturate poisoning, and presumably represent levels from which recovery may not occur despite active treatment. The material reported upon here, however, was obtained from subjects who died without treatment.
Conclusions

The figures reported in this paper have been calculated assuming an extraction rate of $80 \%$ They must be readjusted to a supposed $100 \%$ extraction rate for comparison with the figures of other authors who have not made any allow ance for incomplete extraction of the barbiturate from the blood. The blood barbiturate leve found at necropsy are included, as readjusted in Table I for comparison with the lower lever quoted by other authors as causing unconscious ness. It will be seen that the lowest levels cof? respond closely. It is therefore suggested that the blood levels producing unconsciousness or coma provide a useful guide to the levels causings death in those found dead, since death will be likely to ensue if such levels are exceeded and no treatment is available.

Where combinations of different types of barbiturate are involved the blood level above which death may occur will be little above the level at which unconsciousness occurs with the shortest-acting barbiturate of the combination by itself.

Death may occur at lower barbiturate levels than those known to produce unconsciousness when these are combined with alcohol or carbon monoxide levels, or with diseases such as severo respiratory conditions or anaemia, not themselves sufficient to cause death.

We wish to thank Dr R. M. Winston and othe⿻ pathologists at Hope Hospital for providing dat: and material from the necropsies they performed.

\section{References}

Bogan, J., and Smith, H. (1967). Analytical investigations barbiturate poisoning: description of methods and $\bar{Q}$ survey of results. J. forens. Sci. Soc., 7, 37-45.

Broughton, P. M. G. (1956). A rapid ultraviolet spectrophoto metric method for the detection, estimation and identif cation of barbiturates in biological material. Biochem. J 63, 207-213.

Broughton, P. M. G., Higgins, G., and O'Brien, J. R. P. (1956) Acute barbiturate poisoning. Lancet, 1, 180-184. Curry, A. S. (1949). Poison Detection in Human Organs, p. $4 S_{\text {Th }}$
Thomas, Springfield, Ill.

Curry, A. S. (1966). Simple tests to detect poisoning. Ass. clinPath., Broadsheets, 52.

Fisher, R. S. (1949). Barbiturate toxicity. New Engl. J. Med 240, 395-396.

Smith, I. (1958). Chromatographic Techniques, p. 24. Heinemanis London.

Unicam Method Sheet (1960). No. 500/1. Unicam Instruments Limited.

Valov, P. (1946). Rapid detection and determination of barbito urates from postmortem specimens. Ind. Engng Chent? analyt. Edn., 18, 456.

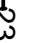

